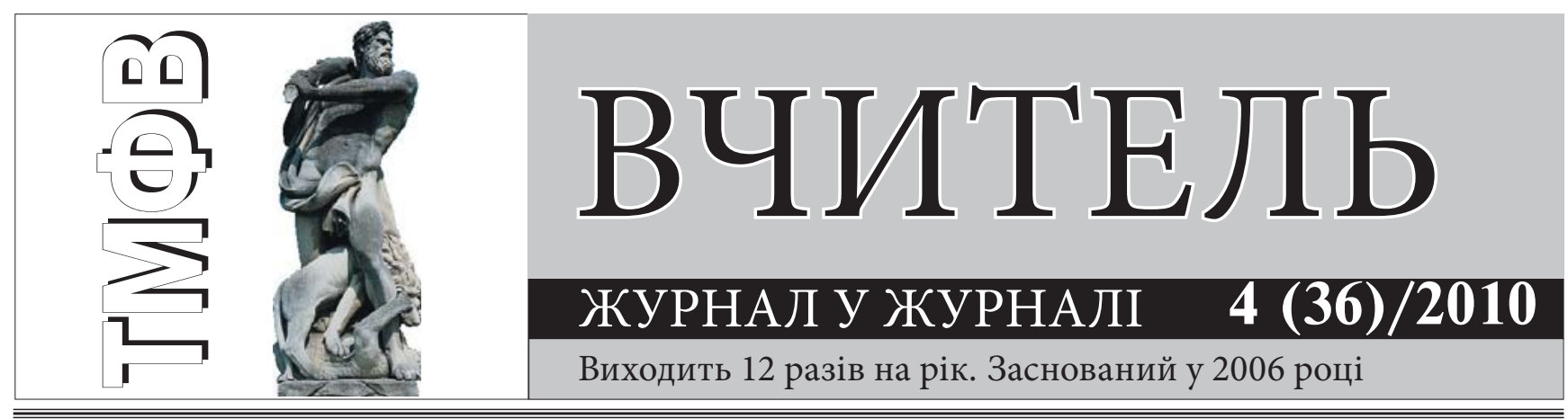

\title{
БІОЛОГІЧНІ, ПСИХОЛОГО-ПЕДАГОГІЧНІ ЗАКОНОМІРНОСТІ рУХОвОї дІяЛЬНОСТІ ЛюдИНИ. ДОПОвІДь І
}

\author{
Худолій О.М. \\ Харківський національний педагогічний університет імені Г.С. Сковороди
}

\begin{abstract}
Анотація. В статті зроблена спроба системного аналізу біологічних, психолого-педагогічних закономірностей рухової діяльності людини.

Ключові слова: системний підхід, рухова діяльність, рухові здібності.
\end{abstract}

Вступ. На сьогоднішньому етапі розвитку фізичного виховання і спорту важливим моментом у побудові тренувальних програм $є$ знання біологічних, психолого-педагогічних закономірностей рухової діяльності людини. Використання цих знань в юнацькому спорті орієнтує на досягнення необхідних показників, які в подальшому будуть сприяти економному витрачанню структурних ресурсів організму, попереджувати явище зношування і забезпечать довговічність в спорті.

Зв'язок роботи з науковими програмами. Робота виконана згідно плану наукових досліджень кафедри ТМФВ Харківського національного педагогічного університету імені Г.С. Сковороди.

Мета дослідження - обгрунтувати біологічні, психолого-педагогічні закономірності рухової діяльності.

Методи дослідження. Для досягнення мети дослідження були використані як філософські, так і загальнонаукові методи, серед яких:

- діалектичний метод;

- системний підхід;

- аналіз і узагальнення науково-методичної літератури.

Виклад основного матеріалу. У статті проаналізовано: поняття "рухові здібності», організм як функціональна система, регулювання напруги м'язів, вегетативне забезпечення м'язів, мускульна система, енергозабезпечення рухової діяльності, загальні закономірності розвитку ру-

() Худолій О.М., 2010. хових здібностей, принципи розвитку рухових здібностей.

\section{Поняття «рухові здібності»}

У вітчизняних дослідженнях проблеми здібностей велика увага приділяється розробці питань про їх суть, співвідношення із задатками, формування і розвиток. При цьому чітко виділилося два підходи до їх розуміння: загальнопсихологічний і диференціально-психологічний. У рамках останнього підходу позначилися - особистіснодіяльнісний і функціональний підходи.

Прихильники загальнопсихологічного підходу (А. Н. Леонтьев, П. Я. Гальперін, В. В. Давидов, Н. Ф. Талызина і ін.) під здібностями розуміють вияв будь-яких можливостей людини. У цьому випадку в центрі проблеми виявляється питання - як ефективніше розвивати здібності всіх людей, тобто проблема набуває психолого-педагогічну спрямованість.

Прихильники диференціально-психологічного підходу підкреслюють відмінність людей за здібностями. У розгляді здібностей з позицій особистісно-діяльнісного підходу, здібності визначаються як властивості або сукупність властивостей особистості, що впливають на ефективність діяльності. Питання про те, які властивості або особливості особистості включати до складу здібностей, залишається дискусійним. Походження здібностей в даному підході пояснюється з позицій діяльності. 
Вважається, що саме діяльність перетворить природжені задатки в здібності.

3 позицій функціонального підходу здібності розглядаються як ступінь прояву якісних сторін елементарних психомоторних функцій, обумовлених задатками (Е.П. Ильин) або властивостей функціональних систем (В.Д. Щадриков). Розгляд здібностей як системних властивостей функціональних систем представляється на сьогоднішній день найпродуктивнішим.

У психології склалася традиція, згідно якої прийнято розрізняти загальні і спеціальні здібності. Так, наприклад, Б. М. Теплов зв’язує загальні здібності з більш загальними умовами провідних форм людської діяльності, а спеціальні - тільки із строго певними видами діяльності.

Під руховими здібностями (Р3), розуміють психомоторні властивості, що визначають ціль, якісні ознаки і робочу ефективність рухової діяльності людини. Рухові здібності - елемент рухової функції (РФ), одної з найбільш складних функцій організму. Головними властивостями РФє здатність до оволодіння і управління рухами в просторі, за часом і ступенем м'язових зусиль.

У психології під «здібністю» розуміються індивідуально-психічні особливості особистості. Для розуміння змісту категорії «здібність» використовуються три найбільш істотні ознаки (Б. М. Теплов, 1941).

1. Під здібністю розуміються індивідуальнопсихічні особливості особистості, що відрізняють одну людину від іншої.

2. Здібностями називаються не усякі індивідуально-психічні особливості особистості, а тільки ті, що впливають на успішність в якій-небудь діяльності чи деяких видів діяльності.

3. Здібності - це такі індивідуально-психічні особливості, що пояснюють легкість і швидкість придбання знань, умінь і навичок.

Цим трьом ознакам відповідають швидкість, координація, сила, рухова витривалість і гнучкість. Поперше, перелічені здібності $\epsilon$ особливостями особистості, що відрізняють одну людину від іншої. По-друге, вони впливають на успішність спортивної діяльності. По-третє, пояснюють легкість і швидкість придбання умінь та навичок виконання рухових дій. 3 точки зору функціонально-генетичного підходу, перелічені характеристики рухової функції також $€$ «здібностями». По-перше, тому, що вони є якісною стороною рухової функції. Подруге, тому, що вони зумовлені задатками. Генетична обумовленість хисту доказана в ряді досліджень, проведених на монозіготних близнятах (А. Анастазі, 1982; В. М. Заціорський, Л.П. Сєргієнко, 1975).

Як відзначає В.С. Фарфель (1977), рухові здібності людини забезпечені рядом фізіологічних сис- тем організму: власне руховою системою, системою управління рухами спільно з системою сприймання і переробки інформації, системою енергетичного забезпечення м'язової роботи, системою регуляції функцій і інтеграції робочого процесу, нарешті, специфічно людською системою - вищих психічних функцій. Кожна з них морфологічно і функціонально закладена в генетичному апараті людини i це визначає характер її рухових здібностей.

Проте треба підкреслити, що здібності - це високий рівень прояву якісної сторони функції, обумовлений задатками. У такому випадку і рухова функція - це результат від рухових здібностей інтегрованих в руховій дії, результат рішення нового рухового завдання найбільш раціональним способом чи доцільного використання рухових навичків (руховий досвід).

Природженими задатками Р3 виступають анатомічні і психічні особливості особистості. Моторні задатки, розвиваючись на основі адаптаційних змін в організмі, переростають у відповідні Р3.

Ю.В. Верхошанський (1988) виділяє чотири конкретні форми Р3, що для умов спортивної діяльності можна вважати основними:

моторна оперативність (прудкість) - здібність, що визначає мінімальну тривалість реалізації рухової дії чи ії елементів у відсутності значного зовнішнього опору руху;

координаційні здібності, що характеризують можливості спортсмена до ефективного рішення рухового завдання за рахунок раціональної організації м'язових зусиль;

силові здібності, що характеризують можливості спортсмена до вияву робочих (рухових) зусиль для подолання чималого зовнішнього опору;

рухова витривалість - здібність до довготривалого виконання м'язової роботи на необхідному рівні їі ефективності.

Гнучкість розглядають як чисто фізичну властивість рухового апарату, як умову до повноцінного прояву Р3 (Ю.В. Верхошанський, 1988). Якщо під гнучкістю розуміється рухливість в суглобах, то такий підхід не викликає сумніву. У спорті ж під гнучкістю розуміється здібність людини до досягнення великої амплітуди в русі, що виконується. У цьому випадку ми маємо справу зі здібністю, що розвивається на основі задатків (рухливість в суглобах, м'язовий тонус, будівля м'язів).

\section{Організм як функціональна система}

Функціональна система - одиниця інтеграції цілого організму, що складається динамічно для досягнення будь-якої його пристосовчої діяльності і завжди на основі циклічних взаємовід- 
носин вибірково об'єднує спеціальні центральнопериферійні утворення (П.К. Анохін, 1978, 1980).

Рухова пристосовча діяльність зв'язана з цілісною реакцією організму. Для виконання довільного руху необхідно володіти надлишковим запасом інформації для вироблення програми дій. Зіставлення іiі з поточними аферентними сигналами, що надходять у мозок, створює модель руху (рис. 1).

Процес переробки аферентної інформації представляє початкову фазу будь-якої цілісної інтегральної діяльності. При цьому еферентні збудження визначають якість, направлення реакції, а також забезпечують саме начало руху, в той час як зворотні аферентації грають вирішальну роль в формуванні адекватних рухових реакцій на зміну зовнішньої ситуації.

Стадія аферентного синтезу, згідно теорії П.К. Анохіна, включає такі компоненти:

1) домінуючу мотивацію, яка утворюється у спортсмена на основі психологічного усвідомлення головної мети рухової дії;

2) пам'ять, яка обумовлена генетичним і індивідуальним досвідом протягом тривалого часу тренувальної і спортивної діяльності;

3) обставинна аферентація, сприйняття якої може стати у спортсменів пусковим сигналом;

4) пускова аферентація, яка утворюється збудженням пускових подразників (умовних).

П.К. Анохін $(1979,1980)$ відзначає, що зворотні аферентації, що виникають у будь-якому руховому акті, потрібно поділити на дві цілком різноманітні категорії, а) рухи, що спрямовують і б) результативну аферентацію. Перша аферентація представлена в основному пропріоцептивними імпульсами від м'язів, які здійснюють рух, друга аферентація завжди комплексна і охоплює всі аферентні ознаки, що стосуються самого результату розпочатого руху. Важливим моментом $є$ і те, що вегетативні компоненти умовної реакції є органічним складником всякої цілісної реакції.

Численні дослідження свідчать, що виконання рухових дій супроводжується вегетативною аферентацією. Це призводить до формування моделі, образу основних параметрів результатів дії на основі аферентного синтезу (К.М. Биков, 1947; ЖанФрансуа Ле Нi, 1973).

На думку П.К. Анохіна, стадія формування акцептора результату дії послідовно змінюється формуванням самої цілеспрямованої дії, яку сам автор назвав «стадією еферентного синтезу». Сутність цієї стадії полягає в узгодженій мультипараметричній взаємодії соматичних, вегетативних і гуморальних компонентів для досягнення кінцевого корисного результату дії. Отже, еферентний синтез $\epsilon$ така стадія цілеспрямованої поведінки, під час якої на основі аферентного синтезу і прийняття рішення утворюється визначена взаємодія вегетативних, соматичних і гуморальних компонентів для досягнення необхідного результату. Еферентний синтез здійснюється поетапно і включає раніше заготовлену програму (еферентний інтеграл), а також «підгонку» одних компонентів відносно інших.

д

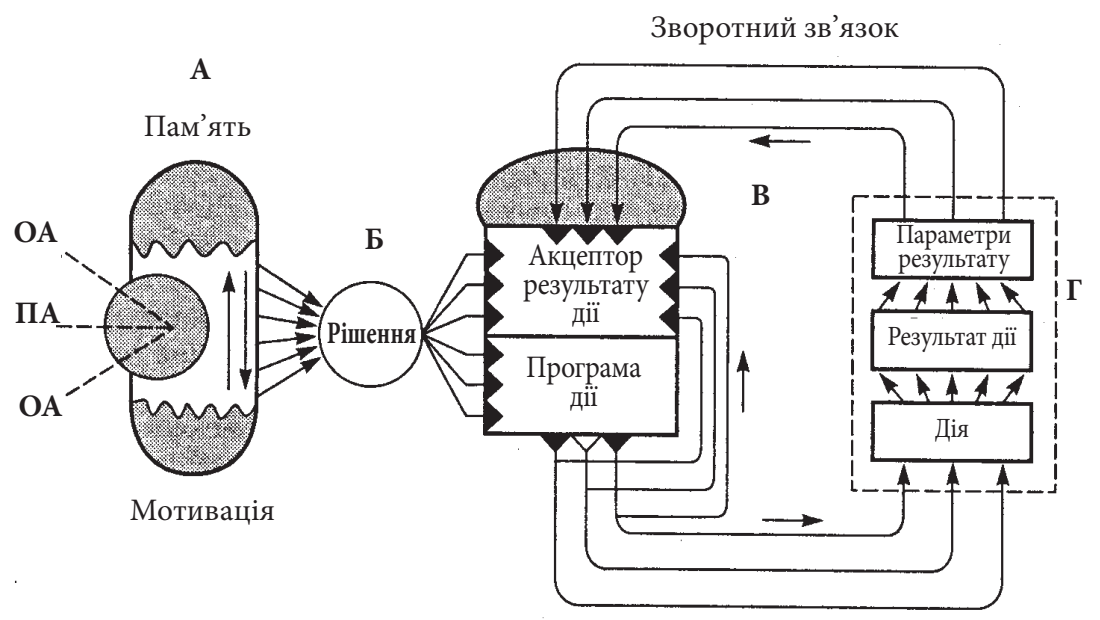

Еферентні збудження

Рис. 1. Загальна архітектура функціональної системи (за: П.К. Анохіним). А - стадія аферентного синтезу; ОА - обставинна аферентація; ПА - пускова аферентація; Б - прийняття рішення; В формування акцептора результату дії і еферентної програми самої дії; Г-Д - отримання результатів дії і формування зворотної аферентації для співставлення результатів із запрограмованими 
Наступає етап програмування дії або поведінки в цілому. Програмування рухових дій повинне передбачати параметри рухів (простір, швидкість, темп, зусилля) і хід рухів в деталях (черговість вступу м'язів в дію).

У програмуванні вірогідності майбутнього реагування важливу роль грає біологічна мотивація.

Мотиваційне збудження, що виникає на основі внутрішньої потреби, укладає в своїй архітектоніці властивості тих подразників, які приводять до задоволення даної потреби: впливаючи на коркові клітини, воно створює особливу хімічну «налаштованість». Така налаштованість клітин визначає їх реакцію, завдяки чому здійснюється активна фільтрація сенсорної інформації. Таким чином, мотиваційне збудження визначає активне використовування і підбір спеціальних подразників зовнішнього світу, сигналізуючих про об'єкти, здатні задовольнити початкову потребу організму. Це випереджаюче віддзеркалення результату діяльності формується на основі аферентного синтезу.

У здійсненні екстрених довільних дій особлива роль належить передбаченню дій, здійснюваних свідомо, усвідомлено програмованих.

Програмування дій і діяльності з урахуванням прогнозу ситуації здійснюється в трьох можливих варіантах: за наявності повної інформації, за наявності часткової інформації і при повній відсутності інформації. Ці варіанти відповідають вірогідності від одиниці до нуля. Природно, програма досягнення мети складається з урахуванням цих трьох варіантів.

Після закінчення програмування слідує сигнал до реалізації програми і виконання самої програми (дія).

Людина повинна знати, як поетапно і в цілому здійснюється програма, і у разі відхилення від програми внести виправлення, що повертають реакції системи в запрограмоване русло. Контроль за діями здійснюється за допомогою зворотної аферентації.

Зворотний зв'язок - це інформація про те, що відбулося або відбувається в даний момент у функціональній системі, як здійснюються дії, які їх результати. Якщо інформація про рухи поступає 3 дистантних аналізаторів (зорового, слухового, тактильного), то говорять про зовнішній зворотний зв'язок. Якщо інформація про рухи поступає з пропріорецепторів м'язів, сухожиль, зв'язок і суглобових сумок, то говорять про внутрішній зворотний зв'язок. За допомогою зовнішнього зворотного зв'язку людина дізнається про результат вчиненої дії, а за допомогою внутрішньої перш за все про те, як здійснювався рух. На підставі аналізу цієї інформації він може побічно судити і про результат дії, якщо має вже досвід зіставлення внутрішньої інформації із зовнішньою (наприклад, спортсмен тільки за м'язовими відчуттями може судити про те, наскільки вдалою була його спроба).

Зовнішні і внутрішні зворотні зв'язки взаємодоповнюють один одного, хоча і грають різну роль на різних етапах навчання. На перших стадіях оволодіння руховими діями провідна роль належить зовнішньому зворотному зв'язку (зоровому і мовному), по мірі ж формування навички все більшу роль відіграє внутрішній зворотний зв'язок, оскільки підвищується роль м'язового відчуття i воно може забезпечити більшу точність рухів, ніж зоровий контроль.

Зворотний зв'язок включає не тільки сигнали 3 рецепторів, розташованих в працюючих органах (ефекторах). Головне в зворотному зв'язку - це встановлення за допомогою зворотної інформації, на якій стадії рішення задачі або досягнення мети знаходиться в даний момент функціональна система (або людина). Знаючи це, людина може далі планувати свою діяльність. Для того, щоб це взнати, треба звірити (порівняти) інформацію, що поступає по каналах зворотного зв'язку, з інформацією, що відображає те, що повинно бути. Нервові утворення, що здійснюють функцію звірення, названі П. К. Анохиным - «акцептором дії». У результаті цього порівняння виникає сигнал узгодження або розузгодження, який передається в програмуючий апарат і ураховується в управлінні дією. До виконавчих органів посилається «санкціонуюча аферентація». Цей сигнал приводить або до продовження дії (якщо програма не виконана, але дія здійснюється відповідно до неї), або до зупинки (припиненню діiі), якщо програма повністю виконана, або до переробки програми (якщо потрібний результат у цій програмі не досягається).

Важливо відзначити, що за допомогою звірення різних видів інформації передбачається хід дії в майбутній миті, тобто апарат звірення допомагає здійснювати не тільки кінцевий (результуючий) контроль, але і поточний.

Звичайно, не слід вважати, що зворотний зв'язок завжди забезпечує точне виконання дій. Точність може бути не досягнута через запізнювання звірення і видачі сигналу до коректування програми, а також через те, що для звірення подається невірний еталон.

Таким чином, моторну діяльність забезпечують:

- центральна нервова система;

- вегетативні системи (живлення, газообмін, виділення);

- нервово-мускульна система (механічна робота і енергоутворення в м'язах).

Основна роль в організації і забезпеченні напруженої мускульної діяльності належить моторній і вегетативній системам, які здійснюють свою функцію під контролем ЦНС. 


\section{Регулювання напруги м'язів}

Спортивна діяльність зв'язана з безперервним корегуванням взаємодії організму і середовища. В управлінні довільними рухами беруть участь всі відділи ЦНС: від спинного мозку до вищих коркових відділів рухового аналізатору.

Складна ієрархія відношень між нижчими і вищими відділами ЦНС $є$ однією з необхідних передумов адаптації до мускульної діяльності. Зовнішня механічна ефективність робочих зусиль м'язів визначається і лімітується потужністю потоку ефекторної імпульсації, що йде з центральної моторної зони до мотонейронів. Чим більша інтенсивність роботи вимагається від м'язів, тим більшу потужність центральної імпульсації вони запрошують.

У процесі мускульної діяльності ЦНС регулює:

1) частоту імпульсації;

2) ступінь синхронізації збуджуючих впливів на мотонейрони;

3) кількість рекрутованих рухових одиниць (PO) (внутрішньом'язова координація);

4) погодження активності скорочення мускульних груп, що втягуються в роботу (міжм’язова координація).

\section{Вегетативне забезпечення м'язів}

Вегетативні функції - функції вегетативної нервової системи в регулюванні діяльності внутрішніх органів і підтриманні гомеостазу (Н.A. Фомін, Ю.Н. Вавілов, 1991).

На рис. 2 представлена схема вегетативного забезпечення роботи м'яза за А.В. Коробковым, С.А. Чесноковой (1987). Дихальна і серцево-судинна системи доставляють кисень до працюючих м'язів і частково вилучають з них продукти обміну $\left(\mathrm{CO}_{2}\right)$. Транспортна функція визначається станом дихального апарату, серцево-судинної системи.

Центральна нервова система забезпечує системи організму інформацією про стан внутрішніх органів (інтерорецептори).

Системи виділення (нирки, шлунково-кишковий тракт, органи зовнішнього дихання) виводять з організму кінцеві і окремі проміжні продукти обміну речовин.

Розглянута схема (рис. 2) в загальних рисах характеризує системну сутність функціонування організму в умовах напруженої рухової діяльності. При цьому провідна роль належить мускульній системі в цілісному характері реагування організму на підви-

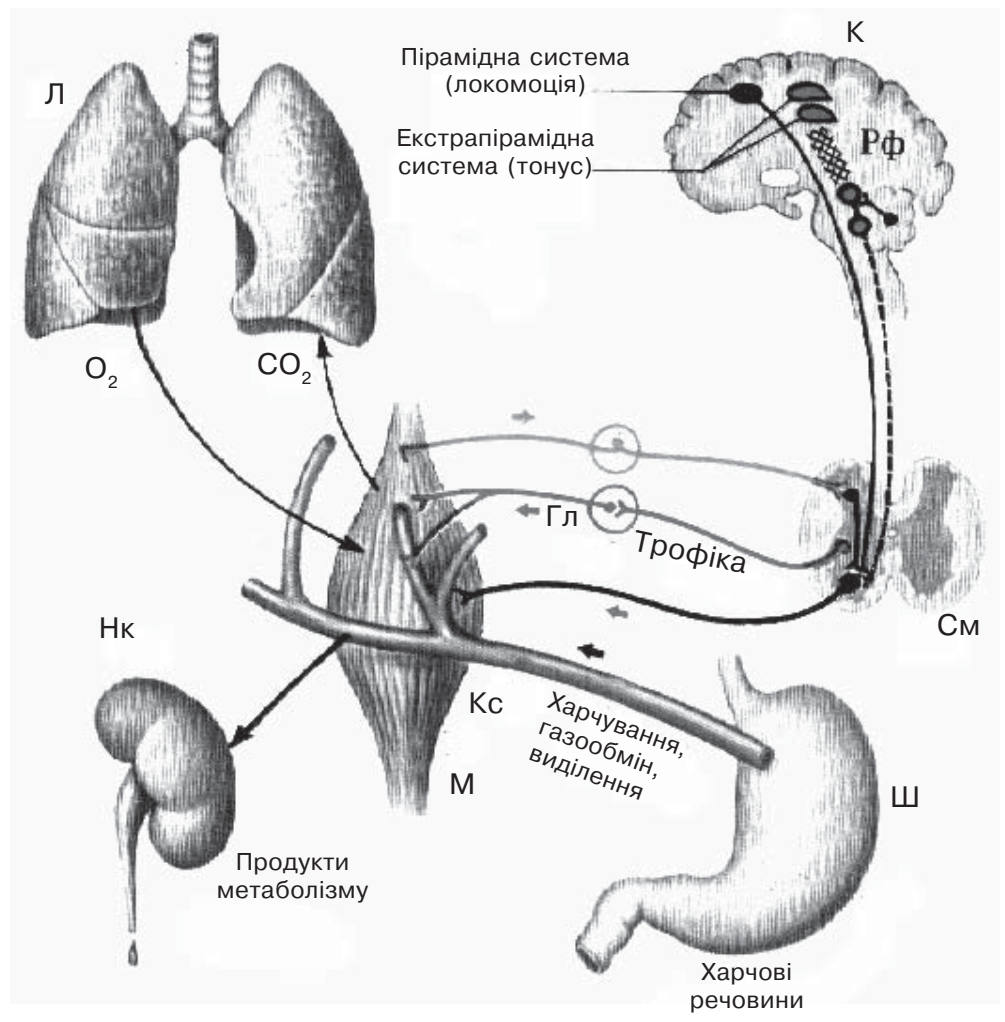

Рис. 2. Вегетативне забезпечення роботи м'яза

(за: А.В. Коробковым, С.А. Чесноковой, 1987)

Нк - нирка, Л - легені, К - кора мозку, РФ - ретикулярна формація,

Кс - кровеносні судини, Ш - шлунок, Гл - симпатичні ганглії,

См - спинний мозок 
щену рухову активність. Більш детальне викладення даного питання можна знайти в спеціальній літературі (Н.А. Фомін, Ю.Н. Вавілов, 1991; В.І. Козлов, Д.А. Фарбер, 1983; Н.Н. Яковлєв, 1983; Н.А. Фомін, В.П. Філін, 1986).

\section{Мускульна система}

У залежності від ступеня збудження і характеру зміни довжини м'яз може проявляти зусилля в різних режимах. У циклічних згинаннях-розгинаннях тіла одна і та ж мускульна група послідовно проходить наступні режими: а) спочатку, натягуючись під дією зовнішнього імпульсу, вона розслаблюється (уступаючий режим), б) продовжуючи натягатися, починає напружуватися, скорочується (режим, що переборює); в) знов, переходячи до розслаблення, продовжує в силу інертності руху ланки скорочуватися (балістичний режим). Наведене чергування режимів роботи м'язів характерне для виконання фізичних вправ. Одна з важливих особливостей такої роботи - підготовка робочого акту м’яза іiі попереднім натягуванням при уступаючій роботі. Попереднє натягування м'яза- найважливіша умова ефективності його роботи. Всі спортивні рухи будуються з урахуванням цієї закономірності, бо натягування м’яза призводить до підвищення iii тонусу (ауксотоніï) і збільшення зусилля, що розвивається.

Ауксотонічний режим роботи м'язів яскраво проявляється у кидкових гімнастичних рухах 3 попереднім «замахом». Однак і в багатьох інших ситуаціях попереднє натягування м'язів, у тому числі в стані їхної напруги (що особливо ефективно), використовується для активізації робочих дій (напружене «провалювання» в плечах у махах на бруcax, наскок на прямі ноги і амортизація у відштовхуванні ногами і т. п.). Ю.В. Верхошанский (1988), 3.М. Хусяйнов (1984), С. А. Никитин (1985), П.С. Новиков (1987) спостерігали, що якщо присутнє різке (в оптимальних межах) розтягування м'язів в фазі амортизації, то збільшується швидкість переключення від уступаючої роботи до переборюючої і вище потужність і швидкість їхнього скорочення.

М'язи проявляють зусилля в таких основних режимах:

А. У статичному (ізометричному), де м’яз під час збудження не скорочується. Термін «ізометричний» підкреслює відсутність змін в довжині м'яза під час збудження; змінюється лише його напруга. Такі умови виникають, наприклад, у деяких статичних положеннях тіла, непорушному утриманні вантажу, у спробах підняти непосильного тягаря.

Б. У динамічному режимі. В цьому режимі розвиваються обидві форми механічної реакції м'яза
- напруга і скорочення. У динамічному режимі діяльності протікає робота м'язів як із зменшенням їхньої довжини (робота, що переборює), так i подовженням (уступаюча робота).

Механічні умови роботи м'язів забезпечуються: 1) структурою мускульної тканини, 2) структурою скелетних м'язів, 3) нервовою системою управління мускульними скороченнями.

Мускульні волокна скелетних м'язів, що довільно управляються, покриті сарколеммою, через яку в звичайних умовах легко проникають глюкоза, молочна і піровиноградна кислоти, кетонові тіла, амінокислоти, короткі пептиди, різні іони. В умовах інтенсивної мускульної діяльності відбувається зрушення реакцій в кислу сторону (норма $\mathrm{PH}$ 7,36-7,4). Надлишок молочної кислоти в м'язах може призводити до розладу процесів утворення енергії в окислювальному циклі і накопичуванню iii в фосфагенах - АТФ і КрФ. Молочна кислота слугує джерелом водневих іонів. Їхній надлишок в скорочувальному апараті перешкоджає утворенню актоміозинових містків, само скорочення м'яза ускладнюється (Н.А. Фомін, Ю.Н. Вавілов, 1991).

Саркоплазматична мережа (ретикулум) з'єднує поверхню сарколеми з внутрішнім вмістом мускульних клітин. Безпосереднє відношення до мускульного скорочення мають 4 види білків міофібрил: міозин, актин, тропоміозин і тропонин. У мікроскопічному дослідженні виділяють чергування більш світлих полосок мускульного волокна 3 більш темними. Це так звані диски А (темні, анізотропні, з подвійним промінезламуванням) і диски J (світлі, ізотропні). У дисках А знаходяться товсті міозинові ниті, в дисках J - тонкі актинові ниті, які лише частково заходять в диск. По середині диска J проходить лінія Z, що з'єднує тонкі ниті одну 3 одною і сарколемою. У центральній частині диска А (зона Н) знаходяться тільки товсті ниті. Від товстих нитей відходять відростки з булавовидними стовщеннями на кінцях, від тонких - стріловидні відростки. Згідно гіпотезі змінних нитей під час сполучення цих двох відростків утворяться єднальні перемички між товстими і тонкими волокнами (рис. 3).

У мускульній цитоплазмі знаходяться також мітохондрії. Їхня основна функція - вилучення енергії з харчового субстрата і накопичування іiі в фосфатних зв'язках АТФ. У поперечносмугастій мускульній тканині мітохондрії розташовуються вздовж міофібрил, вони мають зовнішню і внутрішню мембрани з виростами і внутрімітохондральний матрикс, що насичені окислювальними ферментами. Так, в матриксі мітохондрій зосереджені ферменти циклу Кребса, у внутрішній мембрані локалізовані ланцюг переносу електронів і ферменти фосфорування, що забезпечують утворення АТФ 


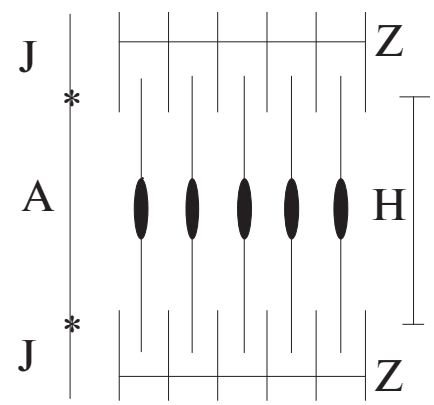

Рис. 3. Будова міофібрилл (М.М. Яковлєв, 1974)

з АДФ (Т.В.Хутієв, Ю.Г. Антомонов, А.Б. Котова, О.Г.Пустовойт, 1991).

Скорочувальні білки складають біля 80 \% всіх мускульних білків. Міозин за своїми властивостями цілком відповідає вимогам, що подаються до скорочувального білка. Він має достатню міцність, виражені фібрилярні та еластичні властивості, характеризується відносно більшим кількісним змістом (біля $40 \%$ ) сухої речовини м'яза.

Дещо поступається міозину за кількісним змістом актин. Він має подібний до міозину і утворює з ним при скороченні порівняно тривкий актоміозиновий комплекс. До кожної молекули фібрилярного актину (F-актин) приєднана молекула АДФ, а до мономірного актину (Ү-актину) - АТФ.

Тропоміозин і тропонин локалізуються на тонких (актинових) протофібрилах.

Між міозином і АТФ існують взаємовідносини ферменту і субстрату: міозин впливає на АТФ, забезпечуючи іiі розщеплення; АТФ змінює скорочувальні властивості міозину, збільшуючи його еластичність. Однак цей факт не може пояснити, чому для отримання енергії природа обрала настільки складне сполучення. Очевидно, зі складністю структури зв'язаний не тільки процес виділення енергіï, але і наступна iї трансформація, тобто самий механізм мускульного скорочення.

У механізмі мускульного скорочення важливу роль грає $\mathrm{Ca}++$, іони якого під час збудження мускульного волокна перекочуються з саркоплазматичного ретикулуму до скорочувальних білків - актину і міозину. У розслабленому м'язі актин і міозин взаємно слабко відштовхуються, бо несуть негативний заряд.

Під час збудження м'яза Са++ утворить комплексні зв'язки між АДФ, фіксованої на фібрилярному актині, і АТФ, зв'язаної з міозином. Ланцюг «АТФ-міозин» виявляється розтягнутим внаслідок електростатичного відштовхування між негативно зарядженою АТФ і негативно зарядженою підставою ниті міозину. Іон $\mathrm{Ca}++$ нейтралізуе негативний заряд АТФ, що призводить до коагулювання ланцюга «АТФ-міозин». Зв'язана з нею нить актину переміщується в напрямку до міозину з одночасним зміщенням (ковзанням) вздовж ниті міозину.

3 початком скорочення АТФ зміщується до активного центру міозину, що призводить до відщеплення кінцевого фосфату молекули. Руйнування структури АТФ викликає розірвання зв'язку між міозином і актином. Ресинтез АТФ на міозині призводить до розпрямлення поліпептидного ланцюжка «міозин-АТФ» і продовженню скорочувального акту з активацією нових дільниць актину і міозину.

Окрім стимулювання актино-міозинового комплексу Са++ виконує роль депресора тропонина. У розслабленому м'язі тропонин попереджає взаємне зближення протофібрил актину і міозину. Будучи зв'язаним кальцієм, тропонин не перешкоджає цьому зближенню і наступному разщепленню АТФ. Розслаблення м'яза починається з швидкої абсорбціїіонів Са++ саркоплазматичною мережею каналів. При цьому відновлюють свої властивості тропонин і тропоміозин. Акто-міозиновий комплекс руйнується: актин і міозин взаємно відштовхуються, призводячи м'яз в розслаблений стан (Н.А. Фомін, Ю.Н. Вавілов, 1991).

М'язи людини здатні як до швидкісних скорочень і прояву значних зусиль, так і до тривалої роботи в умовах стомлення, що розвивається. Це можливо передусім в зв'язку з морфофункціональними властивостями м'язів. У м'язі розрізняють повільні і швидкі волокна.

Повільні волокна (І тип, низькопорогові, окислювальні або оксидативні) більш пристосовані забезпечувати відносно невеликі по силі і тривалості скорочення, характерні для довгочасної роботи на витривалість.

Швидкі волокна (II тип, високопорогові, гліколітичні) не здатні до великої витривалості, однак пристосовані для швидких і сильних, але короткочасних скорочень.

Повільні волокна використовують головним чином аеробний окислювальний шлях ресинтезу АТФ, чому сприяють багата капілярна мережа, підвищений вміст міоглобіну, мітохондрій, в яких протікають окислювальні процеси, висока активність окислювальних ферментів.

Швидкі мускульні волокна використовують анаеробний гліколітичний шлях енергопродукції. Вони мають високу активність гліколитичних ферментів, підвищений вміст глікогену, мале число капілярів, менш мітохондрій, міоглобіну.

Волокна II-го типу більш схильні до продукції лактату, а волокна I-го типу беззупинно екстрагують лактат з крові і волокон II-го типу і окисляють його. Метаболізм у волокнах II-го типу відбувається швидше, ніж у волокнах I-го типу, тому різниця 
в швидкості протікання цих процесів сприяє накопичуванню лактата в м’язах і крові. Інтенсивне тренування підвищує окислювальні властивості волокон І-го типу і спроможність м'язів утилізувати лактат.

Серед швидких мускульних волокон виділяються два підтипи, що розрізняються активністю окислювальних і гліколітичних ферментів:

- швидкі окислювально-гліколітичні (підтип IIA);

- швидкі гліколітичні (підтип IIB).

3 функціональної точки зору волокна IIA типу розглядаються як проміжні між повільними (тип I) i швидкими (підтип IIB) волокнами.

Відношення двох основних типів волокон регулюється головним чином генетичним чинником.

Нескінченна різноманітність довільних рухів від елементарних форм до складнотехнічних вправ, що зустрічаються в спортивній практиці, - підкоряються загальним психофізіологічним закономірностям організації руху.

Н.А Бернштейн $(1940,1966,1991)$ описав чотири рівня організації руху - A, B, C i D.

Рівень А. Імпульси рівня А забезпечують скелетним м'язам не тільки тонус і тонічні скорочення, вони можуть дуже тонко управляти збудливістю як спинномозгових пускових клітин, так і прикріплених до них міонів.

Рівень В - рівень мускульно-суглобного зв'язування, відбиває в собі принцип сенсорних корекцій.

Рівень C - рівень управління рухами. Використовує - екстрапірамідну і пірамідну рухову систему. Завдяки даному рівню ми можемо вірно оцінювати кути і напрямки, дізнаємось і відтворюємо рухи.

Рівень D - рівень дії. Всі рухи, що виконуються під контролем даного рівня зв'язані між собою логікою завдання, що вирішується. Рівень D координує роботу всіх рівнів, що висловлюється в спроможності вирішувати нову рухову задачу найбільш раціональним способом або доцільно використовувати рухові навички (руховий досвід).

За М.О. Бернштейном (1991), низові фонові рівні побудов (А, В, С) виробляють рухи-ланки, потрібні для якої-нибудь ланцюгової дії, не самі по собі, не за власним почином, як вони виробляють, наприклад, ходу, біг або кидок, а по прямим і точним заявкам від рівня дії (D). Під час вироблення нової рухової навички центральна нервова система спершу прощупує і проектує, де взяти найбільш підхожі корекції для кожної послідовної ланки дії і якому фоновому рівню потрібно його у відповідності з цим передоручити.

Очевидно, що механізми організації руху описати тільки лише з позицій фізіології і дати їм пояс- нення неможливо, бо в діях людини завжди присутнє психічне.

Єдність цільового, смислового і моторного компонентів складає психомоторну структуру дії, що виступає як механізм досягнення мети.

На рис. 4 представлений механізм організації довільного руху, що включає ряд блоків: стратегія руху, тактика руху, сенсорний фон, корекція.

У стратегічному блоці важливу роль в будові руху грає мотивація як механізм запуску програми руху.

Доведено, що виконання довільних рухів зв'язане з двома формами моторних програм. Перша програма отримала назву механізму центральних команд. Центральна команда - це така моторна програма, в якій жорстко закладені просторові і часові параметри руху, що дозволяє досягнути високого ступеня точності і економності реакції (Е. Taub, A.J. Berman, 1968). Вважається, що формування образу (енграмми) руху є здебільшого кортикальною функцією, організація ж довільного руху за часом — функція підкоркових структур. Головну роль в часовій організації швидкого руху грає мозочок. Друга програма механізм кільцевого регулювання. Це така моторна програма, в якій коррекція здійснюється на основі інформації, одержуваної за зворотними зв'язками від периферійних рецепторів. Рухи, регульовані за кільцевим механізмом носять назву довільних.

Реалізація складної рухової дії включає три послідовні фази - підготовчу, виконавчу і оціночну.

У підготовчій фазі передбачається мотивоване моделювання способу рішення рухової задачі і на основі мотивація - запуск генетичних програм забезпечення рухової діяльності (блок стратегії руху).

Виконавчою фазою рухової дії $є$ власне процес рішення рухового завдання.

Згідно сучасним уявленням довільна рухова діяльність здійснюється за попередньою програмою (просторово-часовою), що прогнозує досягнення кінцевого результату. Запуск тієї або іншої програми залежить від аферентних сигналів про сенсорний фон руху. Результат дії і зіставлення його 3 цільовим прогнозом дозволяє вносити корективи в рух і наближатися до запланованого ефекту (рис. 4, блок тактика руху, сенсорний фон руху, корекція).

Оціночна фаза реалізації складної рухової дії передбачає оцінку виконання і у випадку необхідності внесення корекції в програму дії.

Корекція в програму руху може вноситися як на рівні свідомого, так і несвідомого регулювання.

\section{Енергозабезпечення рухової діяльності}

Головним джерелом енергії для клітинних функцій є розпад АТФ на АДФ. Основний 


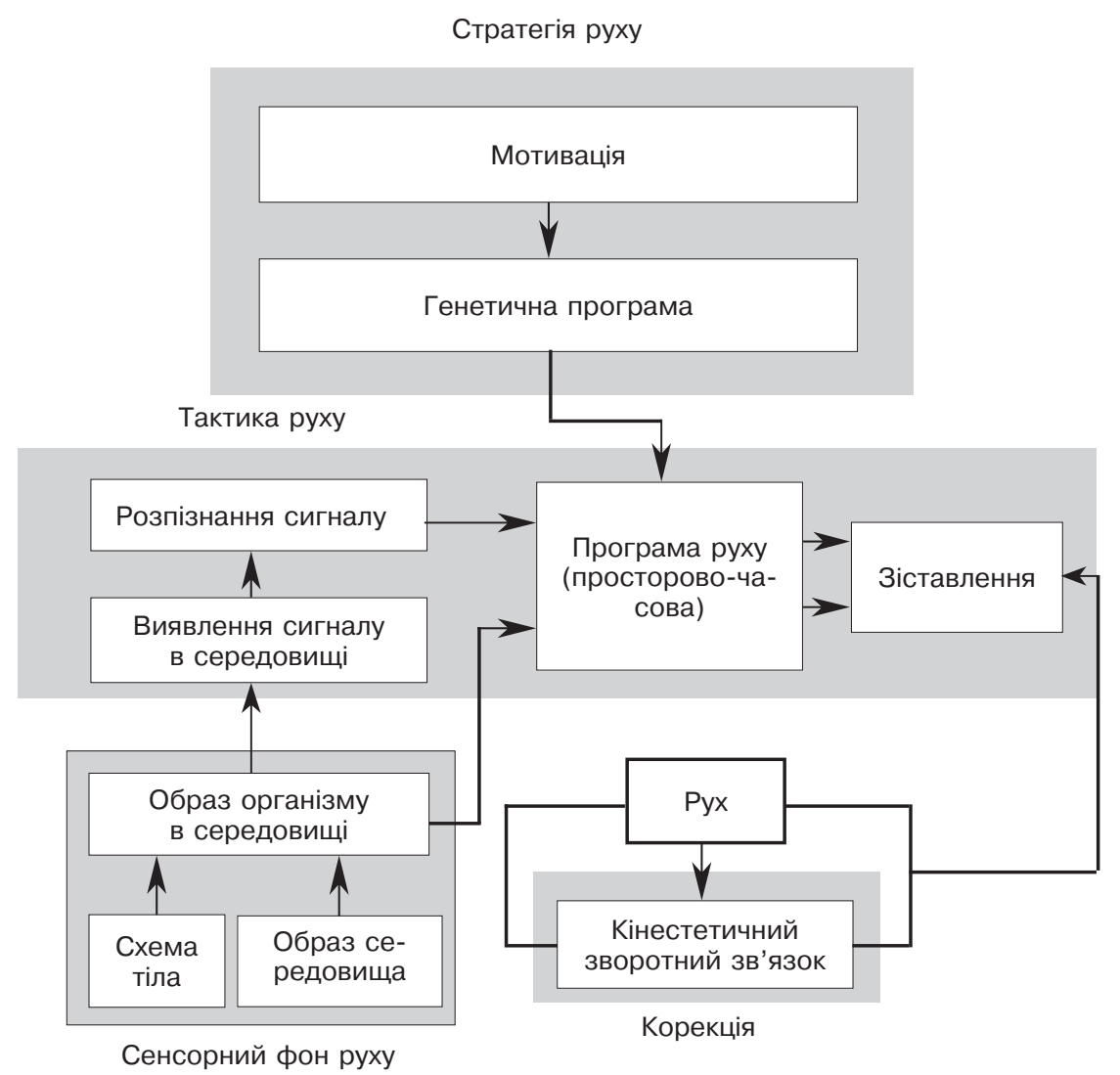

Рис. 4. Механізм організації руху (за: А. Батуєв, О. Таіров, 1978)

механізм утворення АТФ з АДФ - це біологічне окислення, яке являє собою окислювально-відновні реакції, що протікають в клітинах організму, в результаті яких складні органічні речовини окисляються при участі специфічних ферментів, що доставляються кров'ю.

Кінцеві продукти біологічного окислення енергія, що вивілняється в процесі біологічного окислення, частково виділяється у виді тепла, основна ж частина йде на утворення молекул фосфороорганічних сполучень (АТФ). Схема перетворення речовин в організмі представлена на рис. 5 .

Таким чином, єдиним прямим джерелом енергії для мускульного скорочення служить аденозинтрифосфат (АТФ). Для того щоб мускульні волокна могли підтримувати скільки-небудь тривале скорочення, необхідне постійне відновлення (ресинтез) АТФ з такою ж швидкістю, 3 якою він розщеплюється.

Ресинтез АТФ може здійснюватися трьома основними шляхами:

- креатинфосфатним;

- гліколітичним (анаеробне джерело);

- окислювальним (аеробне джерело).

У цих механізмах для ресинтезу АТФ використовуються різні енергетичні субстрати. Вони відрізняються за енергетичною ємністю, тобто за максимальною кількостю АТФ, і за енергетичною потужністю, тобто максимальною кількістю енергіï, що виділяється за одиницю часу.

Креатинфосфатний механізм має найбільшу потужність, що приблизно в 3 рази перевищує максимальну потужність гліколітичного і в 4-10 раз окислювального механізмів ресинтезу АТФ. КрФ механізм грає вирішальну роль в енергозабезпеченні робіт граничної потужності. Запаси АТФ і КрФ в м’язах обмежені, ємність КрФ механізму невелика, робота з граничною потужністю може тривати на протязі 6-10 с.

Гліколітичний механізм забезпечує ресинтез АТФ і КрФ за рахунок анаеробного розщеплення вуглеводів і глюкози - з утворенням молочної кислоти (лактата). У якості одної з умов активізації гліколіза виступає зниження концентрації АТФ і підвищенні концентрації продуктів іï расщепления - АДФ і неорганічного фосфору. Це активізує ключові гліколитичні ферменти (фосфофруктокиназа, фосфорилаза) і завдяки цьому посилюють гліколіз. По мірі накопичування лактата в процесі гліколізу активна реакція внутрішнього середовища $(\mathrm{pH})$ зміщується в кислу сторону, відбувається гальмування активності гліколітичних ферментів, що знижує швидкість гліколізу і кількість енергії (АТФ), що утвориться за одиницю часу. Тому єм- 
ність гліколітичного джерела лімітується головним чином не змістом відповідних субстратів, а концентрацією лактату.

Частина лактату, що утворилася в процесі роботи, окислюється в м'язах, інша переходить в кров і надходить в клітини печінки, де використовується для синтезу глікогену. У свою чергу, глікоген розщепляється до глюкози, що переноситься в м'яз кров'ю і забезпечує ресинтез мускульного глікогену, що витратився під час мускульної діяльності.

Потужність гліколітичного механізму в 1,5 рази вище, ніж окислювального, а енергетична ємність в 2,5 рази більше, ніж креатинфосфатного.

Окислювальний механізм забезпечує ресинтез АТФ в умовах безперервного надходження кисня в мітохондрії мускульних кліток і використовує в якості субстратів окислення вуглеводи (глікоген і глюкозу), жир або ліпіди (жирні кислоти) і частково білки (амінокислоти).

Співвідношення між окислювальними субстратами визначається відносною потужністю аеробної роботи (в \% від МСК - максимального споживання кисня). Під час виконання легкої роботи на рівні 50 \% від МСК з граничною тривалістю до декількох годин більша частина енергії для скорочення м’язів утвориться за рахунок окислення жиру (ліполіза). Під час більш важкої роботи (більш $60 \%$ від МСК) значну частину енергопродукції забезпечують вуглеводи. У роботах, близьких до МСК, більша частина енергопродукції йде за рахунок окислення вуглеводів.

Окислювальний механізм має найбільшу енергетичну ємність. В разі використання вуглеводів його ємність визначається запасом глікогену в м’язах і печінці, а також можливістю печінки утворювати глюкозу в процесі роботи не тільки за рахунок розщеплення глікогену (глікогеноліз), але і за рахунок утворення глюкози (глюконеогенез) 3 лактата й інших речовин (амінокислот, пірувата, гліцерину), що попадають в печінку з кров’ю. Найбільшу енергетичну ємність з усіх мускульних джерел енергії має жир, що робить його придатним для виконання тривалої роботи відносно невеликої потужності при повному кисневому забезпеченні. Однак вуглеводи мають серйозну перевагу перед жиром за кількістю АТФ, що утвориться, на одиницю кисня, що споживається. Особливо ефективно в цьому плані окислення мускульного глікогену,

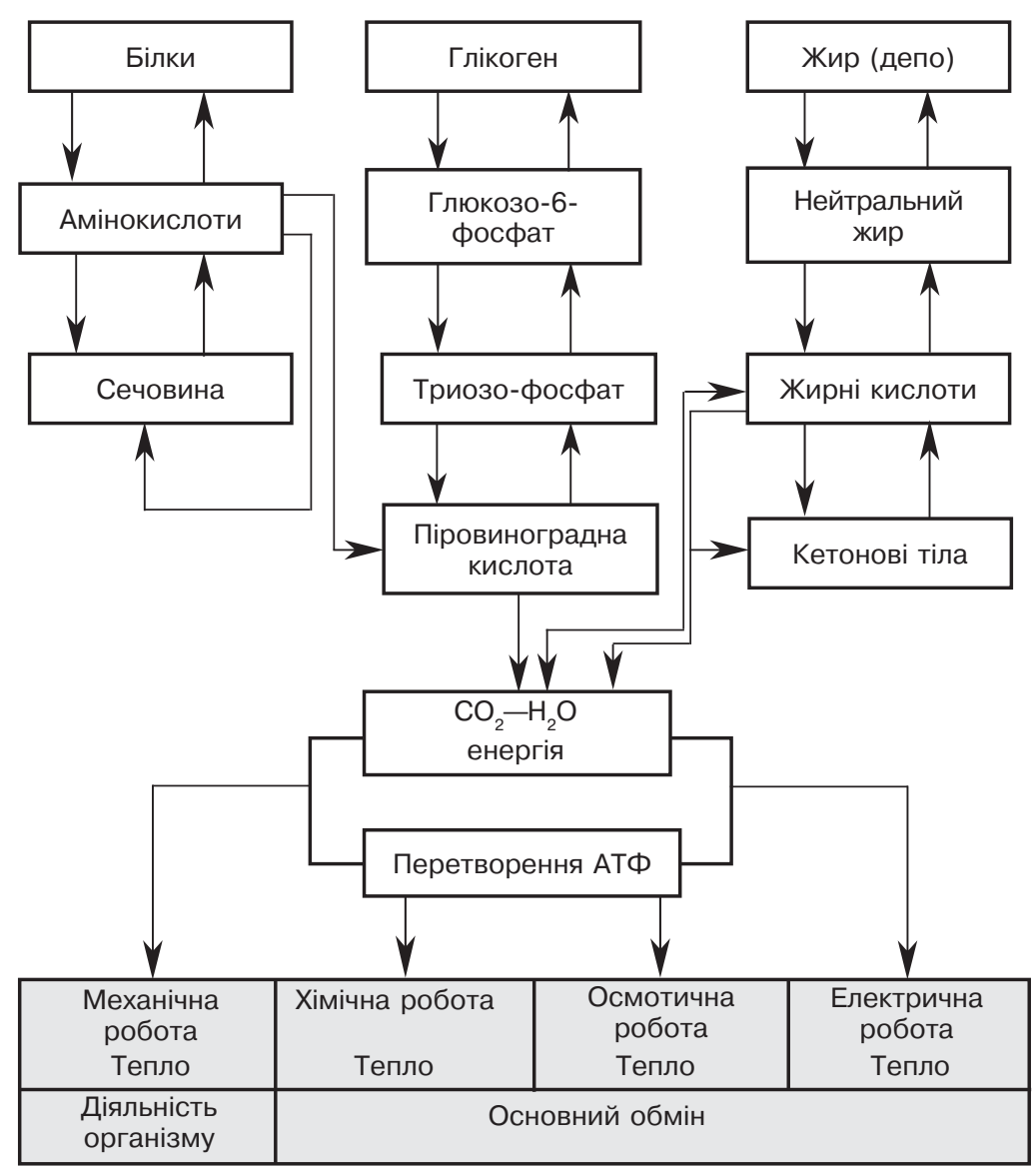

Рис. 5. Схема перетворення речовин в організмі (за: А.В. Коробковым, С.А. Чесноковой, 1987) 


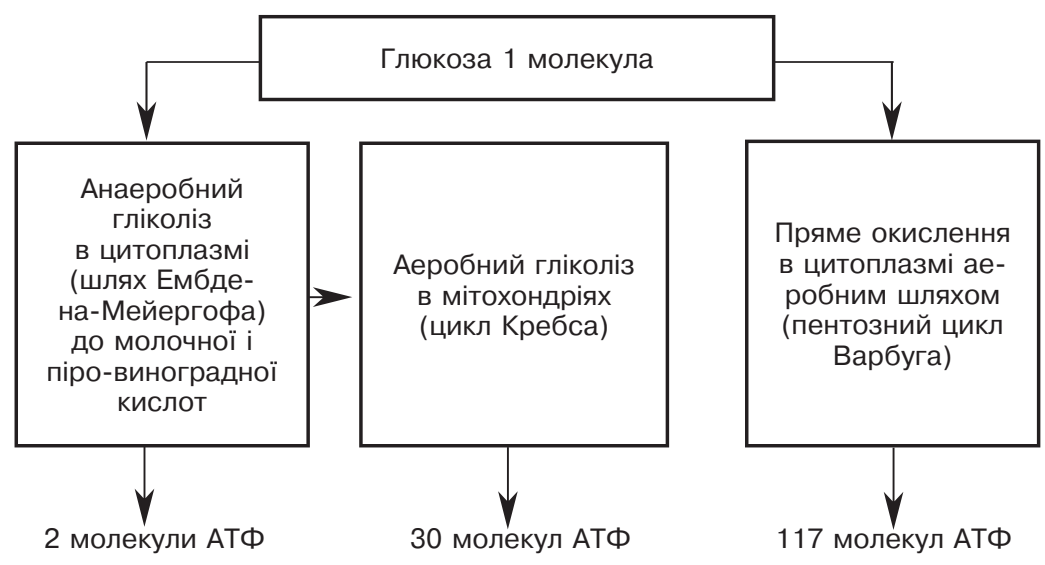

Рис. 6. Розщеплення глюкози й утворення АТФ

(А. В. Коробков, С. А. Чеснокова, 1987)

що має найбільшу енергетичну ефективність, удвічі більшу, ніж в окисленні жиру.

Аеробний механізм ресинтезу АТФ відрізняється найбільшою продуктивністю і економічністю. Так, в анаеробному гліколізі 1 молекула глюкози утворить 2 молекули АТФ, в той час як аеробний гліколіз дасть 30 молекул АТФ (див. рис. 6).

У переході до аеробного окислення видаток мускульного глікогену зменшується і все більше використовується глюкоза, яка приноситься кров’ю. У зв'язку з тим, що вона утворюється з глікогену печінки, він швидко витрачається і вміст його зменшується. Починають окислятися джерела енергії невуглеводної природи (жирні кислоти, кетонові тіла). Відбувається мобілізація ліпідів з жирової тканини. У крові збільшується вміст як нейтрального жиру, так і продуктів його розщеплення — гліцирина і жирних кислот. Підвищується вироблення печінкою кетонових тіл і надходження їх в кров. Вміст кетонових тіл в крові збільшується по мірі зниження в ній кількості молочної кислоти. М'язи інтенсивно забирають з крові і окисляють вільні жирні кислоти і кетонові тіла. Підсилення окислення ліпідів сприяє підвищенню економічності витрачання джерел енергії, бо вони володіють більшим запасом енергії, ніж вуглеводи (рис. 5).

Для аеробного окислення необхідно гарне постачання організму киснем, що є кінцевим акцептором електронів і водневих ядер, що віднімаються від окислених речовин. Однак і під час гарного постачання кисню ресинтез АТФ може виявитися малоефективним із-за часткового розлагодження дихання з фосфорилюванням. Справа в тому, що ферменти аеробного окислення, поєднаного 3 фосфорилюванням, зосереджені в мітохондріях іфіксовані в суворо певному порядку на мембранах гребнів. Так здійснюється послідовний перенос електронів і протонів по дихальному ланцю- гу і поєднане зним дихальне фосфорилювання (Т.В. Хутієв, Ю.Г. Антомонов, А.Б. Котова, О.Г.Пустовойт, 1991).

\section{Загальні закономірності розвитку рухових здібностей}

Розвиток рухових здібностей людини здійснюється на основі визначених закономірностей (А.П. Матвеев, 1990; А.А. Гужаловский, 1977, З.И. Кузнецова, 1975; Т.В. Карсаевская, 1970; Е. П. Ильин, 2003). Серед яких виділяють: гетерохронність, різнонаправленність і наявність сенситивних періодів.

Першою особливістю вікового розвиткує те, що різні рухові здібності досягають свого максимального розвитку в різному віці, що свідчить про гетерохронність (різночасність) дозрівання функціональних систем (рис. 7). За даними Е.П. Ильина швидкість і частота рухів досягають максимального розвитку вже в $13-15$ років. До цього ж віку закінчується в основному розвиток координаційних можливостей людини: влучності балістичних рухів, точності диференціювання амплітуд і зусиль. Пізніше досягає максимального розвитку витривалість до статичних зусиль (в 18-20 років). М'язова сила і витривалість аеробна до динамічної роботи досягають максимуму в 25-30 років. У жінок терміни досягнення максимуму розвитку рухових здібностей менші на $1-2$ роки.

Другою особливістю вікового розвитку рухових здібностей є різнонаправленість їх зміни в окремі вікові періоди, зокрема - в період статевого дозрівання. Швидкісно-силові здібності в цей період розвиваються інтенсивно, а координаційні (точність диференціювання і відтворення амплітуди і зусиль) - часто навіть погіршуються. Відбувається 


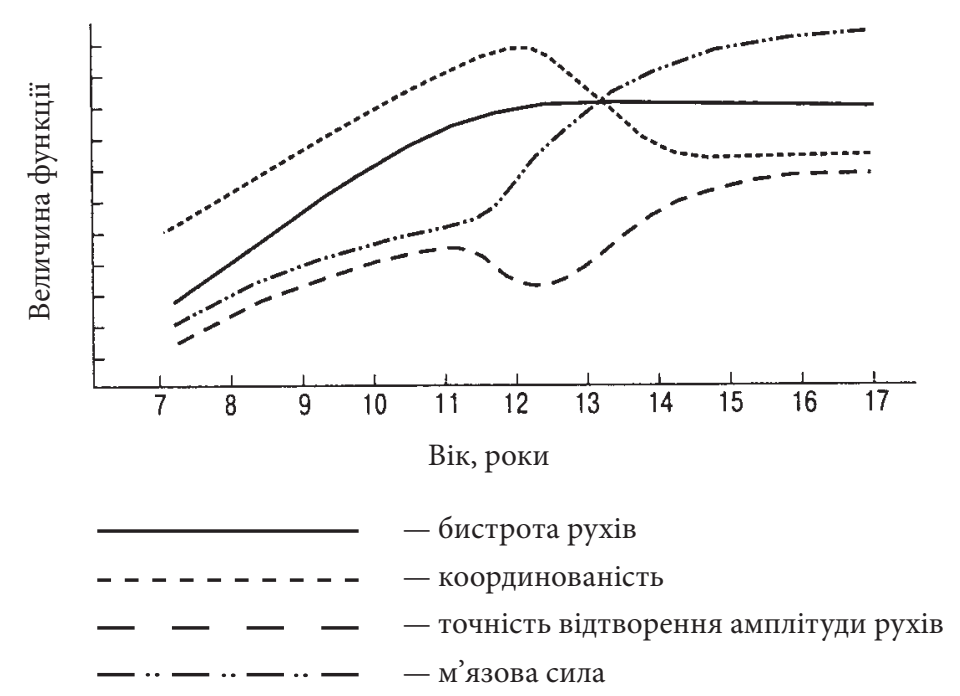

Рис. 7. Гетерохронність і різноспрямованість розвитку рухових здібностей у шкільному віці (за: Е.П. Ильиным, 2003)

це тому, що в цей період спостерігається гормонна перебудова організму, що призводить до зростання збудження і рухливості нервових процесів, які сприяють вияву швидкісно-силових здібностей, але утрудняють управління відповідністю рухів через спотворення суб'єктивних еталонів рухів у бік їх збільшення.

Слід ураховувати і анатомо-морфологічні зміни, що відбуваються в цей період у дітей. Збільшення довжини тіла і кінцівок приводить до зміни біомеханічної структури рухів, що вимагає вироблення нових координацій.

Третьою особливістю вікового розвитку рухових здібностей є наявність сенситивних періодів (критичних), під час яких спостерігається найбільший розвиток тієї або іншої функції за умови спрямованого впливу (табл. 6.1 і 6.2).

3 початку XX століття в різних областях біології і науки про людину з'являються вказівки на існування особливих періодів розвитку, званих критичними, або чутливими.

У середині тридцятих років ХХ ст. Л. С. Выготский говорить про необхідність вивчення сенситивних періодів для встановлення оптимальних термінів навчання. Він пропонує в процесі навчання ураховувати не тільки нижні вікові межі оптимального періоду, але і верхні, а також звертає увагу на те, що чинники середовища, що оптимально впливають на певному етапі розвитку, в інші періоди можуть мати нейтральну або навіть негативну дію.

Вчення про періоди чутливості має велике значення для педагогіки, бо виявляє межі для оптимального досягнення результатів у формуванні рухових навичок і інтелектуальних здібностей.
Створення оптимальних умов фізичного i психічного розвитку дитини вимагає вивчення меж морфологічної готовності різних систем організму до певного характеру діяльності і залежності розвитку тієї або іншої системи від характеру і своєчасності їі функціонування, а також вимагає з'ясування взаємодії, взаємовпливу сенситивних періодів різних систем для формування організму як цілого.

Можна припустити, що критичні періоди виступають як фази найбільшої реалізації потенцій організму в даному відношенні. Невикористовування сенситивного періоду для досягнення оптимальних результатів призведе до того, що не всі потенції організму в досягненні кінцевого результату будуть реалізовані або, принаймні, на їх реалізацію буде потрібно більш довгий час.

Дослідження сенситивних періодів дозволяє глибше зрозуміти діалектичний зв'язок процесу розвитку людського організму із складним комплексом умов середовища. Відома спільність закономірностей «відображення» у вегетативній і центральній нервових системах свідчить про те, що ця здібність до утворення онтогенетичних програм $€$ достатньо широкою загальнобіологічною закономірністю.

Дослідження меж сенситивних періодів і можливих відмінностей глибини впливу в рамках цього періоду на онтогенетичну програму індивіда дозволяє з'ясувати і можливість свідомої зміни природного ходу подій в онтогенетичному розвитку. Істотні зміни в умовах життя людини минулого і нинішнього століття, що привели до феномена акселерації, можливо, привели і до зміни меж сенситивних періодів. Але навряд чи можна припустити, що більш раннє досягнення певного зростання має прямим наслідком таке саме раннє досягнення рухової готовності 
Сенситивні періоди для розвитку рухових здібностей (за: А.А. Гужаловским, 1974)

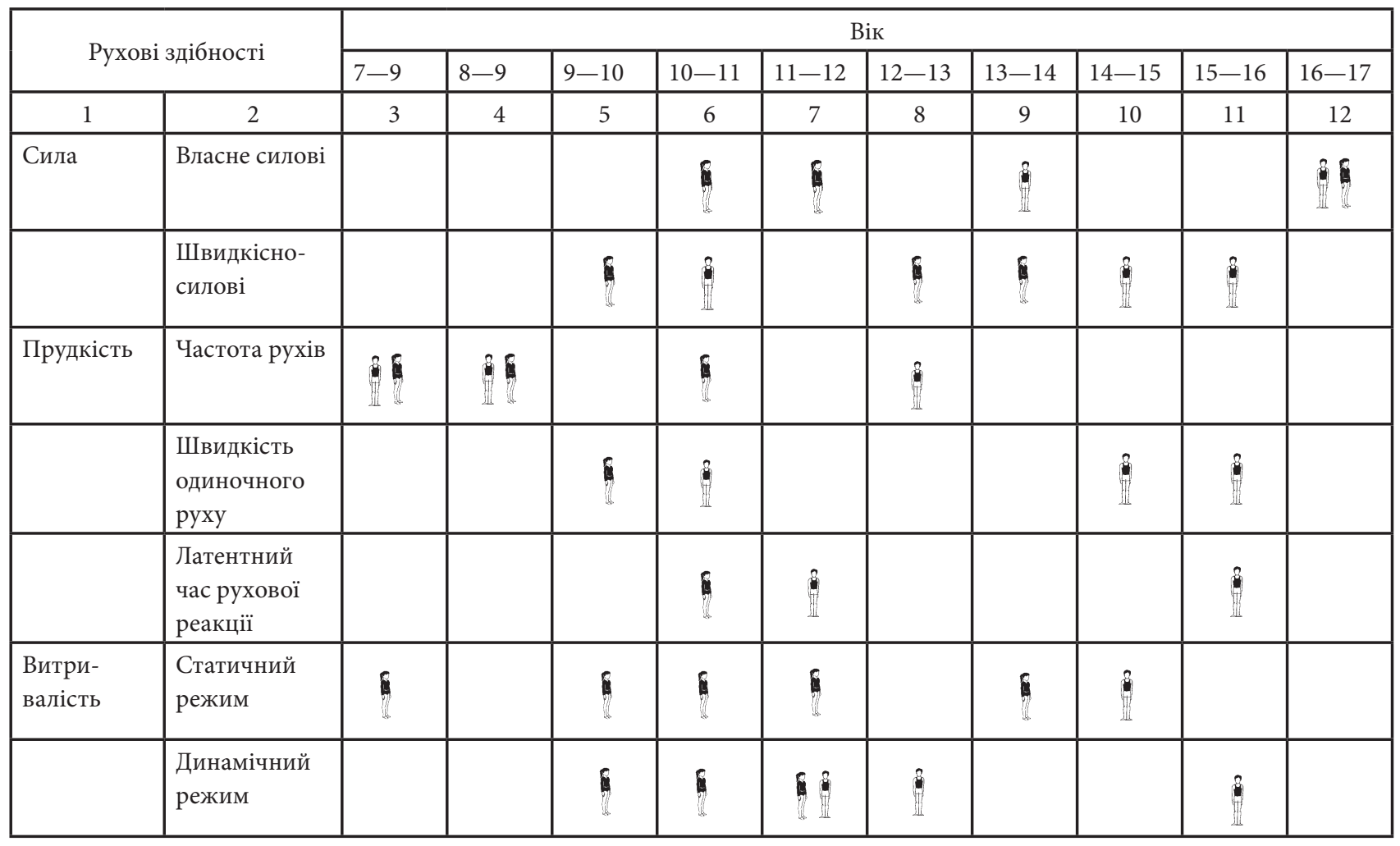

\begin{tabular}{|c|c|c|c|c|c|c|c|c|c|c|c|}
\hline & $\begin{array}{l}\text { Зона макси- } \\
\text { мальної ін- } \\
\text { тенсивності }\end{array}$ & & & & ( & & & (8) & I & 8 & \\
\hline & $\begin{array}{l}\text { Зона субмак- } \\
\text { симальної ін- } \\
\text { тенсивності }\end{array}$ & & & 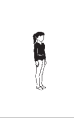 & I & & & ( & & 1 & I \\
\hline & $\begin{array}{l}\text { Зона великої } \\
\text { інтенсивності }\end{array}$ & & $\mathbb{1}$ & 8 & 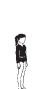 & & & & & II & 8 \\
\hline & $\begin{array}{l}\text { Зона помірної } \\
\text { інтенсивності }\end{array}$ & & 8 & & 8 & & 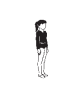 & & & 8 & \\
\hline $\begin{array}{l}\text { Координа- } \\
\text { ція }\end{array}$ & $\begin{array}{l}\text { Прості коор- } \\
\text { динації }\end{array}$ & 8 & 8 & & & & 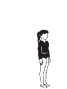 & & II & & \\
\hline & $\begin{array}{l}\text { Складні коор- } \\
\text { динації }\end{array}$ & & & (1) & 8 & & 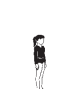 & & I & & \\
\hline & Рівновага & i & 89 & 5 & & . & & & 8 & & \\
\hline & $\begin{array}{l}\text { Точність } \\
\text { рухів }\end{array}$ & & 81 & & & & 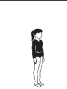 & & 8 & & \\
\hline Гнучкість & & . & 81 & i & & is & 8 & & is & & (5) \\
\hline
\end{tabular}


Сенситивні періоди для розвитку координаційних здібностей здібностей (із: Е.П. Ильин, 2003)

\begin{tabular}{|c|c|c|c|c|c|c|c|c|c|}
\hline \multirow{2}{*}{$\begin{array}{l}\text { Координаційні } \\
\text { здібності }\end{array}$} & \multicolumn{9}{|c|}{ Вік } \\
\hline & 6 & 7 & 8 & 9 & 10 & 11 & 12 & 13 & 14 \\
\hline $\begin{array}{l}\text { Управління три- } \\
\text { валістю м'язових } \\
\text { напружень }\end{array}$ & 8 & 80 & 8 & & & & & & \\
\hline $\begin{array}{l}\text { Диференціювання } \\
\text { просторових і часо- } \\
\text { вих характеристик }\end{array}$ & 8 & 8 & & 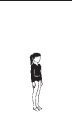 & 80 & 8 & & & \\
\hline $\begin{array}{l}\text { Управління часом } \\
\text { реакції на слухові і } \\
\text { зорові сигнали }\end{array}$ & & & 8 & 8 & I & 8 & & & \\
\hline До ритму & & 1 & 8 & 80 & 8 & & & & \\
\hline $\begin{array}{l}\text { До орієнтації в про- } \\
\text { сторі }\end{array}$ & & & & & 8 & & 8 & 8 & 8 \\
\hline До рівноваги & & & & (1) & 80 & 进 & & & \\
\hline
\end{tabular}

до різних видів діяльності. Так, В. В. Бунак проаналізував динаміку в показниках фізичного розвитку в період зростання з показниками фізичної дієздатності і констатує, що розміри цих змін неадекватні: зсув у розмірах тіла більш явний і перевершує по величині наростання фізкультурних показників, тобто укрупнення розмірів тіла не супроводиться адекватним приростом індексів фізичної дієздатності. Не виключено, що таке неспівпадання тенденцій $€$ наслідком відставання програми розвитку рухової діяльності, орієнтованої на паспортний вік, а не на вік соматичного розвитку.

Серед багатьох питань, що виникають у зв'язку з проблемою критичних періодів, дуже важливими є такі - що означає невикористовування сенситивного періоду для становлення тієї або іншої системи організму? Чи означає це, що в становленні організму реалізована одна 3 двох або декількох рівних можливостей, а інші втрачені, або така втрата можливості є дефектом розвитку? Напевно, для деяких можливостей в розвитку людини, вірне останнє припущення, оскільки очевидно, що не всі можливості в розвитку людини рівноцінні і здійснення однієї 3 можливостей робить неможливою реалізацію інших потенцій даної системи.

Накопичений до теперішнього часу матеріал дозволяє припускати, що прикладність концепції критичних періодів розвитку до проблеми оптимі- зації фізичного виховання дітей має велике теоретичне і практичне значення (А.А. Гужаловский, Т.В. Карсаевская, Е.П. Ильин, З.И. Кузнецова).

Досягнення більш значних спортивних результатів на початку спортивних занять в юнацькому періоді може служити непрямим свідоцтвом правильності припущення про те, що успішне використовування підвищеної пластичності у формуванні загальнорухової підготовки в рамках сенситивної готовності збільшує резерви фізичної дієздатності організму в більш пізньому віці. У відомому значенні нереалізовані сенситивні можливості організму стають гальмом для подальшого досягнення оптимальних можливостей, властивих організму людини.

Четвертою особливістю вікових змін рухових здібностей є наявність критичних періодів інволюuіi (КПІ), під час яких у дорослих спостерігається найбільше зниження окремих рухових здібностей (А. А. Гужаловский).

П'ятою особливістю вікових змін рухових здібностей $є$ наявність індивідуальних відмінностей в темпах їх розвитку, що обумовлене біологічним віком, в якому відбувається статеве дозрівання: у одних (акселератів) воно наступає раніше, у інших (ретардантів) значно пізніше. Тi, у кого це відбувається раніше, мають перевагу в термінах розвитку рухових здібностей. 
Спостерігаючи вікову динаміку рухових здібностей, слід ураховувати не тільки, а може бути і не стільки, паспортний вік, скільки біологічний. Залежно від стадії біологічної зрілості ця динаміка може істотно відрізнятися від тієї, яка виходить з урахуванням тільки паспортного віку.

\section{Висновки:}

1. Рухова діяльність людини спрямована на розвиток рухової функції. Рухова функція — це результат від рухових здібностей інтегрованих в руховій дії, результат рішення нового рухового завдання найбільш раціональним способом чи доцільного використання рухових навичок (руховий досвід).

2. Розвиток рухової функції забезпечується цілісною реакцією організма. У функціональну систему для досягнення пристосовчої реакції об'єднуються центральна нервова, вегетативна і нервово-мускульна системи.

3. Розвиток окремих компонентів рухової функції в сенсетивні періоди можуть сприяти економному витрачанню структурних ресурсів організму, попереджувати явище зношування і забезпечувати довговічність в спорті.

Перспективним напрямком розвідок $є$ визначення особливостей формування рухової функції у дітей і підлітківв в процесі фізичного виховання і спортивної діяльності.

\section{Список літератури}

1. Анохин П.К. Системные механизмы высшей нервной деятельности: Избранные труды / Анохин П.К. - М.: Наука, 1979. - С. 14-100, 353-366.

2. Анохин П. К. Узловые вопросы теории функциональной системы / Анохин П.К. - М.: Наука, 1980. - C. 51-90.

3. Бернштейн Н. А. Очерки по физиологии движений и физиологии активности / Бернштейн Н. А. - М.: Медицина, 1966. - 350 с.

4. Гужаловский А.А. Физическое воспитание школьников в критические периоды развития / Гужаловский А.А. //Теория и практика физической культуры. - 1977. - № 1. - С. 37-39.

5. Гужаловский А.А. Периодизация развития физических качеств у детей школьного возраста / Гужаловский А.А.//Вопросы теории и практики физической
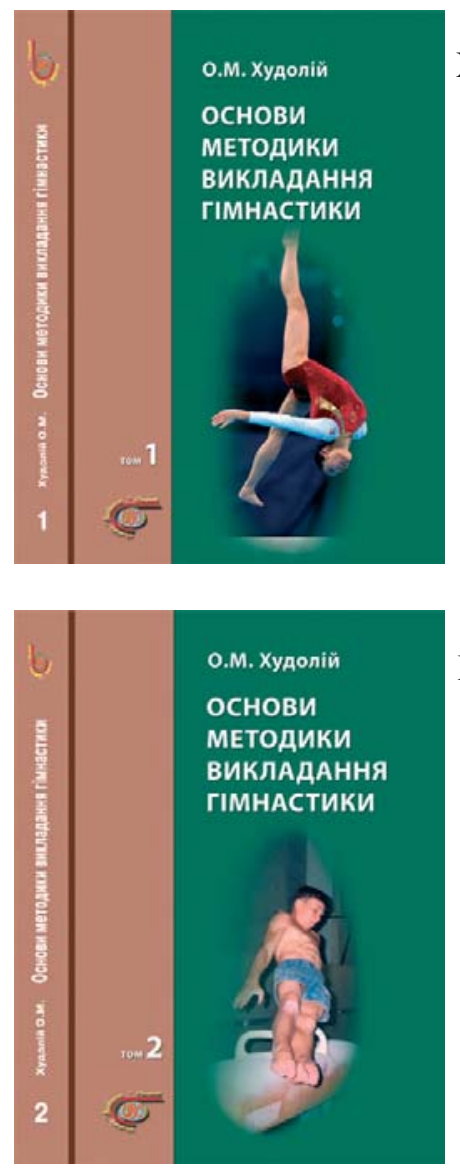

X98

\section{Худолій О.М.}

Основи методики викладання гімнастики: Навч. посібник. У 2-х томах. - 4-е вид., випр. і доп. - Харків: «ОВС», 2008. - Т. 2. - 464 с: іл.

ISBN $966-7858-54-5$.

ISBN 966-7858-56-1(II).

У навчальному посібнику розглянута методика викладання гімнастики в школі і ДЮСШ, а також методика організації і проведення змагань зі спортивної гімнастики.

Посібник рекомендовано викладачам і студентам факультетів фізичного виховання вищих педагогічних навчальних закладів III-IV рівня акредитації та вчителям фізичної культури середніх загальноосвітніх шкіл.

\section{Рекомендовано}

Міністерством освіти і науки України як навчальний посібник для студентів вищих навчальних закладів (лист № 14/18.2-1928 від 17.11.03) 
культуры и спорта: Республиканский межведомственный сборник. - Минск: «Вышэйшая школа», 1983. - Вып. 13. - С. 29-32.

6. Гужаловский А. Проблема «критических» периодов онтогенеза в ее значении для теории и практики физического воспитания / Гужаловский А.А.// Очерки по теории физической культуры. - М.: Физкультура и спорт, 1984. - С. 211-223.

7. Ильин П.Е. Психомоторная организация человека: Учебник для вузов / Ильин П.Е. - СПб.: Питер, 2003. $-384 \mathrm{c}$.

8. Карсаевская Т.В. Социальная и биологическая обусловленность изменений в физическом развитии человека / Карсаевская Т.В. - Л.: «Медецина», Ленинградское отделение, 1970. - С. 116-124.

9. Коробков А. В. Физиология адаптации // Нормальная физиология / Коробков А. В. - М.: Высшая школа, 1980. - С. 443-457.

10. Коробков А. В. Атлас по нормальной физиологии: Пособие для студ. мед. и биолог. спец. вузов / Коробков А. В., Чеснокова С. А./ Под ред. Н. А. Агаджаняна. - М.: Высшая школа, 1987. - 351 с.
11 Кузнецова З.И. Когда и чему. Критические периоды развития двигательных качеств школьников // Физическая культура в школе / Кузнецова 3.И. 1975. - № 1. - С. 7-10.

12. Матвеев А.П. Воспитание физических качеств //Теория и методика физического воспитания: Учеб. для студентов фак. физ. культуры пед. ин-тов / Матвеев А.П. / Под ред. Б.А. Ашмарина. - М.: Просвещение, 1990. - С. $124-136$.

13. Матвеев Л. Принципы теории тренировки и современные положения теории адаптации к физическим нагрузкам / Матвеев Л., Меерсон Ф.// Очерки по теории физической культуры. - М.: Физкультура и спорт, 1984. - С. 224-241.

14. Мохан Р. Биохимия мышечной деятельности и физической тренировки / Мохан Р., Глессон М., Гринхафф П. Л. - Киев: Олимпийская литература, 2001. $-295 \mathrm{c}$.

15. Фомин Н. А., Филин В. П. На пути к спортивному мастерству. - М.: Физкультура и спорт, 1986. $160 \mathrm{c.}$

Надійшла до редакиії 22.02.2010 р.

Худолей О.Н. Биологические, психолого-педагогические закономерности двигательной деятельности человека. Доклад I.

В статье сделанна попытка системного анализа биологических, психолого-педагогических закономерностей двигательной деятельности человека.

Ключевые слова: системный подход, двигательная деятельность, двигательные способности.

Khudolii O.N. Biological, psychological, pedagogical to conformity to the law of motive activity of man. Lecture I. In article sdelanna attempt of systems analysis of biological, psychological, pedagogical to the motive activity of man. Keywords: systems approach, motive activity, motive capabilities. 